\title{
TERTIARY INSECTS FROM KUDIA RIVER, MARITIME PROVINCE, SIBERIA
}

\author{
By T. D. A. Cockerell \\ Of the University of Colorado, Boulder
}

In a previous contribution ${ }^{1}$ I have described two species of insects from the Tertiary rocks of the Kudia River, a tributary of the Amagu, in the Maritime Province of Siberia, North Latitude $46^{\circ}$. During July 1923, my wife and I, assisted by A. I. Lavrushin (or Lavrooshin), investigated this deposit, and collected the insects described below. We also obtained a good collection of plants, which will be described later by Dr. A. Kryshtofovich.

The exposure is very limited, and since it was visited by Mr. Kuznetzov the clay bank above it has fallen, covering the fossiliferous rocks with talus, which rests at such an angle that a little movement brings more down. It was therefore difficult to obtain much material, and the rock itself was comparatively unproductive, a day's labor in splitting it and turning it over sometimes giving little but fragments of Sequoia, Alnus, etc. Some of the best insects were found in the bed of the clear and cool Kudia River. Mr. Lavrushin went up and down the river, and also a considerable distance along the Amagu, in the hope of finding another exposure, but without success. He did, however, find a fragmentary fossil leaf on a hill overlooking the Kudia, but it was not in place. Doctor Kryshtofovich, from the collections of Kuznetzov, has identified a flora of 19 species from this deposit. These species are on the whole such as have been considered characteristic of the Eocene, though at least four are said to range upward to the Miocene, while five are not definitely referred to any species. The only new species (Porana sichota-alinensis) is related to a Miocene fossil. It must also be said, that the aspect of the flora is comparatively modern; in fact there is very little which can not be said to be closely allied to plants still living. We no longer find Sequoia or Ginkgo in the

${ }^{1}$ Proc. U. S. Nat. Mus., vol. 64, art. 13 , no. 2503 , 1924, pp. 1-15, pls. 1-2.

No. 2606.-Proceedings U. S. National Museum, Vol. 68. Art. 5. $53652-25-1$ 
Siberian forests, but the Alnus corylina Knowlton and Cockerell (corylifolia Lesquereux), which is one of the most abundant of the fossils, and is represented by fruits and even what appears to be the bank, is entirely similar in aspect to the alders (Alnus hirsuta) growing in dense thickets at the very place where the fossils are found.

Kryshtofovich figures a Pinus, allied to the American P. ponderosa, with three leaves in the bundle. We found this abundantly, and remarked that no such pine existed in the same region to-day. However, we also found two other species of fossil pines, one with

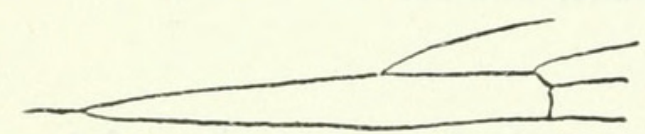

Fig. 1.-PART OF venation OF Phryganea Lavrushini leaves in twos (like $P$. sylvestris) and the other with bundles of four slender leaves. This differentiation of Pinus is suggestive of the Miocene.

In the case of some of these fossil plants, too much importance should not be attached to the specific determination. Thus one of the species reported by Kryshtofovich is Glyptostrobus europaeus (Brongniart.) Of this species Berry writes:

This species is exceedingly common at a large number of localities and horizons in the northern hemisphere throughout the Tertiary period. In North America it is represented from the basal Eocene to the Pliocene, and though it probably includes more than one botanic species no basis for its segregation except by geographic or geologic divisions is discernible.

The insects, although more numerous in species than the recorded plants, will not suffice to define the horizon, though on the whole I should imagine them to be Upper Oligocene or Lower Miocene.

\section{TRICHOPTERA}

\section{Family PHRYGANEIDAE}

PHRYGANEA LAVRUSHINI, new species

Plate 2, fig. 16

Anterior wing about $19 \mathrm{~mm}$. long (the portion preserved $14.3 \mathrm{~mm}$.), width fully $8 \mathrm{~mm}$.; mottled with brown on upper two-fifths, especially toward the base; a well-defined stigmatic cloud; discoidal cell $6.8 \mathrm{~mm}$. long, its base very acute, a large cloud in and above its apical end. Tertiary rocks of Kudia River, Amagu, Siberia, found by my assistant, A. I. Lavrushin, 1923.

Holotype.-Cat. No. 69593, U.S.N.M.

This is a broad-winged species resembling $P$. latissima Ulmer, from Baltic amber. The venation differs from $P$. latissima by $R_{2}$ leaving discoidal cell more basad, about $4.2 \mathrm{~mm}$. from base of cell and $2.5 \mathrm{~mm}$. from separation of $\mathrm{R}_{3}$; separation of $\mathrm{R}_{3}$ to end of discoidal cell only $0.5 \mathrm{~mm}$.; fork at separation of $R_{2}$ very narrow, much 
more so than in P. cinerea, etc. There is an approach to the Florissant Miocene $P$. wickhami Cockerell. In the Tertiary rocks at Posiet, Siberia, Doctor Kryshtofovich obtained cases of Phryganea (P. kryshtofovichi Cockerell), about $7 \mathrm{~mm}$. wide, made of pieses of Sequoia langsdorff spirally arranged exactly as in the living $P$. grandis. The pieces are about $5 \mathrm{~mm}$. long and 1.2 wide. On the other hand, the cases from the Miocene of Oeningen, which Heer named Phryganea antiqua, do not belong to this genus.

\section{AmagupsychinaE, new subfamily}

Wings very broad; anterior wing similar in most respects (including characteristic region at end of cubitus) to that of Phryganea, but possessing a complete median cell, and two simple anals; media four-branched, but the fourth branch arises very obliquely close to the base of the median cell, and after a short distance is connected with the cubitus by a transverse cross vein; thus all five forks are present.

Type.-Amagupsyche, new genus.

This might be regarded as the type of a new family, but the structure so closely simulates Phryganeidae that I believe there is actual affinity, the fossil representing a branch of the phryganeid stem which has not persisted.

\section{AMAGUPSYCHE, new genus}

Anterior wing broad, mothlike, shaped approximately as in Neuronia ruficrus, not hairy, veins pale-brownish; subcosta apparently quite simple, ending very acutely on margin at about level of end of median cell; radius $\left(R_{1}\right)$ stout, simple, not in the least undulate subapically, connected with $R_{2}$ by a transverse cross vein a short distance beyond discoidal cell, the vein $R_{2}$ bent at the cross vein; discoidal cell large, about as long as its stem, but not nearly so long as the distance from its end to apex of wing; side of discoidal between first and second forks somewhat oblique, face on first fork twice as long as that on second; median cell long-cuneiform, about as long as discoidal, cross vein to radius at a less distance from its end than the length of its apical side; first two branches of media (third fork) separating just before end of median cell; $\mathbf{M}_{3}$ continuous to margin in line with lower side of median cell; $\mathbf{M}_{4}$ leaving median cell obliquely very near its base, and connected with cubitus by a cross vein nearly as long as face of discoidal cell on first fork; end of cubitus forming a short triangular fork exactly as in Phryganea; first anal ending at base of cubital fork; second anal quite simple (it is also simple in Maritia, Palaeolepidostoma, Maniconeurodes and Ogmomyia), ending at same point as end of $\mathrm{Cu}_{2}$.

Type.-Amagupsyche perlata, new species. 
The wing spot at the base of the second fork is as in modern Phryganea.

AMAGUPSYCHE PERLATA, new species

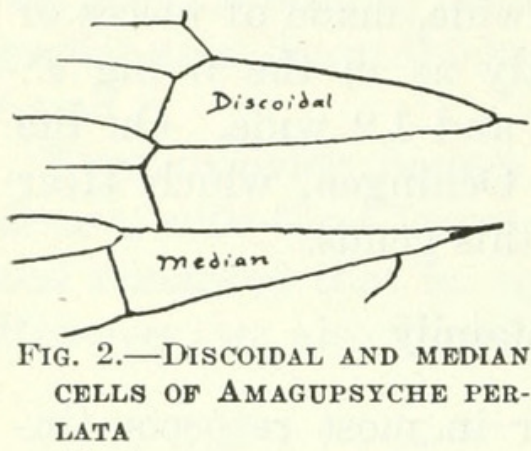

Plate 2, fig. 14

Anterior wing $16 \mathrm{~mm}$. long and 8 broad; uniform dilute fuliginous, not spotted; costal area dark fuscous. Length of discoidal cell $4 \mathrm{~mm}$., its end to apex of wing about $7.5 \mathrm{~mm}$.; length of median cell slightly over $4 \mathrm{~mm}$; length of cellula thyridii $6 \mathrm{~mm}$., its base $4 \mathrm{~mm}$.,

basad of level of base of discoidal; length of second anal $10 \mathrm{~mm}$.

Tertiary of Kudia River, Siberia; both impressions found. Holotype.-Cat. No. 69594, U.S.N.M.

\section{Family LIMNEPHILIDAE \\ INDUSIA COMMINUTA, new species}

Plate 2, fig. 12

Case cylindrical, straight, about $8 \mathrm{~mm}$. long and 3 wide, at first sight appearing as if made of sand grains, but under the microscope seen to be covered with minute irregular vegetable fragments, not so closely disposed as to hide the entire surface. Only in one case is a very small short piece of Sequoia leaf employed. Some specimens are distinctly narrower at one end. Very abundant in Tertiary of Kudia River, Siberia. The name Indusia is employed for caddiscases which cannot be referred to a definite genus. The reference of this and the next to Limnephilidae is provisional.

Holotype.-Cat. No. 69599, U.S.N.M.

\section{INDUSIA SEQUOIAE, new species}

Plate 2, fig. 13

Case cylindrical, straight, about $18 \mathrm{~mm}$. long and 6 wide, composed of vegetable fragments, mainly short pieces of leaves of $\mathrm{Se}$ quoia langsdorfi, arranged irregularly, but obliquely transverse.

Tertiary of Kudia River, Siberia.

Holotype.-Cat. No. 69595, U.S.N.M.

\section{LIMNEPHILUS RECULTUS, new species}

Plate 1, fig. 9

Anterior wing probably $18 \mathrm{~mm}$. long, but only $15 \mathrm{~mm}$. preserved, the base lost; width $7 \mathrm{~mm}$; a apical cells (back to about $7 \mathrm{~mm}$. from apex) clear hyaline, the rest of wing dilute fuliginous, but not 
spotted; costal margin narrowly suffused with dusky to apex; venation so far as visible agreeing with Limnephilus gravidus Hagen, except that the tip of the longer enclosed anal cell is at the same level (distance from base) as the fork of radial sector, indeed slightly more apicad, the wing evidently being shorter. The broad apical portion resembles that of the Limnephilus. End of discoidal cell from tip of wing $7 \mathrm{~mm}$.; length of discoidal cell $5.5 \mathrm{~mm}$.; length of cellula thyridii about $5.3 \mathrm{~mm}$., not going far basad of discoidal; veins delicate, pale-brown; discoidal cell on first fork no longer than breadth of its squarely truncate apex.

Tertiary of Kudia River, Siberia.

Holotype.-Cat. No. 69596, U.S.N.M.

This seems a very convincing Limnephilus, but it must be admitted that the fossil Phryganea longirostris Hagen has a similarly broad wing, while $P$. dubia Pictet (which Pictet took for a Limnephilus) has the frst fork going no great distance basad of apex of discoidal cell. $P$. dubia has a fourth fork, which our fossil lacks. All things considered, this surely must be a Limnephilus; a matter of interest since Limnephilidae are absent from Baltic amber. Assuming that the

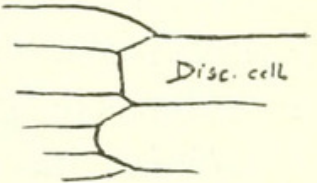

Fig. 3.-END of DISCOIDAL CELL OF LIMNEPHILUS RECULTUS family invaded the Palaearctic region at a later date than the amber, we may get some light on the age of the Siberian deposit. Limnephilidae are found (two species) in the Miocene of Florissant.

A second specimen referred to Limnephilus recultus is less perfect, but shows the base, with both inclosed anal cells as usual, and the characteristic curve in the radius above end of discoidal cell. The apical area is not so conspicuously pale as in the type. The apex of the cellula thyridii is seen to be extremely oblique, a character favoring Phryganea rather than Limnephilus.

\section{COLEOPTERA}

\section{Family CARABIDAE}

PATRobUS(?) KUDIENSIS, new species

Plate 1, fig. 10.

Elytron $7.8 \mathrm{~mm}$. long, 2.9 wide, nearly parallel-sided except at ends; humeral angle rounded, without tooth or prominence; apex broad, not acute, but not truncate; surface as preserved dull, apparently minutely granular, but not punctate, the color coffeebrown; eight well-defined but delicate striae, not counting two fine closely adjacent lines on shelflike outer margin; striae not punctate, and no punctures between striae on disk; submarginal punctures feebly indicated. 
Tertiary of Kudia River, Siberia.

Holotype.-Cat. No. 69597, U.S.N.M.

The general shape of the elytron might suggest Pterostichus or Morio, but there is no humeral projection or point, and the inner basal striae do not conform. As between Patrobus and Scarites I have found it hard to decide, but the elytron agrees better with Patrobus in that the submarginal sulcus fails to reach or approach the apex, and has at its end a row of small punctures. Also, the oblique groove mesad of this is indicated, though feebly. In the genus Patrobus, the species falls near P. californicus Motschulsky, and is quite different from such species of $P$. longicornis Say, in which the striae are punctured. In Leng's catalogue, $P$. californicus and its allies are referred to a distinct genus, Platidius, and our fossil should perhaps stand as Platidius kudiensis.

On the same stone, but on the other side, is a case of Indusia comminuta. It may be added that Patrobus proper is essentially a subarctic genus (Greenland, Alaska, Labrador, etc.), whereas Platidius has its maximum development in more southern regions. This tends to reinforce the suggested reference of the fossil to Platidius.

\section{Family CURCULIONIDAE}

CLEONUS SHAREIPOFFI, new species

Plate 1, fig. 11

Elytron $8 \mathrm{~mm}$. long and 2.6 wide, parallel-sided, as preserved rather dilute brown; base truncate, apex broad but pointed; nine rows of strong punctures, evanescent (apparently abraded) apically, three or four punctures in one $\mathrm{mm}$.; between the rows of punctures are very delicate longitudinal brown lines, not impressed; at the beginning of outer third of apical half is an obtuse longitudinal elevation or shoulder. The punctures are circular, not elongated.

Tertiary of Kudia River, Siberia.

Holotype.-Cat. No. 69598, U.S.N.M.

Numerous Tertiary species have been referred to Cleonus, but few are as convincing as this, which has quite the aspect of the modern genus. I have given it a name commemorating $\mathrm{Mr}$. Shareipoff, head man of the village of Amagu, who gave us much assistance in our undertaking.

ANTHONOMUS AMAGUENSIS, new species

Plate 1, fig. 7

Elytra brown, $4 \mathrm{~mm}$. long and 1.3 wide, base broadly truncate, humeral angles rounded, apex rather acute. Seven longitudinal striae, consisting of rows of shallow punctures as in living species. 
Surface with stout bristlelike structures (bristle-scales), exactly as in the living $A$. grandis Boheman. The apex is more acute than in $A$. grandis, and the punctured striae are fewer, but the specimen (a pair of elytra still joined) presents the dorsal view, and the lateral striae are presumably not visible.

Tertiary of Kudia River, Siberia.

Holotype.-Cat. No. 69612, U.S.N.M.

\section{Family THROSCIDAE}

\section{THROSCUS(?) PERITULUS, new species}

Plate 1, fig. 8

Coffee-brown; prothorax $2 \mathrm{~mm}$. wide and $1 \mathrm{~mm}$. long, broadly rounded, forming less than a semicircle, truncate but not excavated in front, sides rapidly expanding posteriorly to end in a thin and sharp spine or thornlike angle, mesad of which the hind margin is broadly excavated; surface of prothorax and elytra minutely rugose or rugosopunctate; elytra slightly over $3 \mathrm{~mm}$. long, and a little over $1 \mathrm{~mm}$. wide, width of insect at middle of elytra $2.1 \mathrm{~mm}$; elytra with humeral angles prominent; first three-fifths of outer margin straight but the elytra slightly widening to the end of the straight portion, then rapidly contracting to the obtuse apex; no striae or distinct punctures, but some evidence of obtuse ridges, forming a sort of narrow reversed $\mathrm{V}$, in the manner of the Buprestid Anthaxia aeneogaster Castelnau (specimen from near Ward, Colorado, compared). The thorax is wholly different from that of Anthaxia.

Tertiary of Kudia River, Siberia.

Holotype.-Cat. No. 69600, U.S.N.M.

Had I only the elytra, I should imagine this to fall in the Buprestidae, in or near Anthaxia. The thorax is more like that of the Elateridae, except for its shortness. Thus the insect falls best in the Throscidae, but the reference to Throscus is to be taken in the broadest sense. As a possible alternative, I sought among the genera of Nitidulidae, but found nothing closely comparable.

Wickham described a Throscid (Pactopus) from the Miocene of Florissant; the specimen presents a ventral view, whereas ours presents the dorsal.

\section{HYMENOPTERA}

\section{Family MEGACHILIDAE}

MEgACHILE AMAGUENSIS, new species

Plate 1, fig. 1

Anterior wing $9 \mathrm{~mm}$. long and about $3.6 \mathrm{~mm}$. broad; fuliginous, with brown veins; marginal cell narrowly rounded at apex, away from costa; fold across first submarginal cell distinct; second sub- 
marginal cell very long, receiving first recurrent nervure nearly as far from base as the length of first intercubitus, but the second recurrent practically at apex; basal nervure meeting nervulus on the basad side, the latter not in line with it, but directed a little apicad, bulging outwardly. The following measurements are in microns: Second submarginal cell on marginal, 960 ; lower side of first submarginal cell, 1184; first recurrent nervure from basal corner of second submarginal, 480; first recurrent to second (on second submarginal) 1280.

Tertiary rocks of Kudia River, Siberia.

Holotype.-Cat. No. 69601, U.S.N.M.

A true Megachile, by reason of the fuliginous wings resembling some of the modern Indian species, and like them, having the base distinctly pallid, though only for a short distance. The distance of the first recurrent nervure from the base of the second submarginal cell is an unusual feature, which I do not observe in living species

\section{HOMOPTERA}

\section{Family CERCOPIDAE}

PHILAGRA (?) KUDIANA, new species

Plate 1, fig. 3

Hind wing $18.5 \mathrm{~mm}$. long, entirely fuliginous; r.-m. cross vein transverse (vertical), $6 \mathrm{~mm}$. from apex of wing; m.-cu. cross vein strongly oblique, arched, its lower end apicad, about $0.6 \mathrm{~mm}$. from fork of cubitus and a little over $7 \mathrm{~mm}$. from end of upper branch of cubitus; cubital fork wide; second anal undulate, with a strong double curve.

Tertiary rocks of Kudia River, Amagu, Siberia.

Holotype.-Cat. No. 69602, U.S.N.M.

Philagra, a genus now ranging to China, Japan, and Australia, has exactly the same venation, but whether the fossil species had the produced head of Philagra we cannot know. Aphrophora differs by having the lower cross vein vertical, as I have verified by examining various species. Cosmoscarta has this cross vein oblique, but the lower end is basad. This fossil may be compared with Aphrophora angusta Handlirsch, from the Tertiary of Tulameen River, British Columbia. This species is quite as large as ours, but has a cu.-a. cross vein, and a much narrower cell between branches of cubitus.

APHROPHORA PROTOCALLA, new species

Plate 1, Fig. 6

Tegman $13.5 \mathrm{~mm}$. long, 4 broad in middle (clavus missing; costal margin convex, but not excessively so; outer margin about 
$4 \mathrm{~mm}$. long, gently curved, the apex of the tegmen obtuse, not pointed, apex and outer margin being formed as in the oriental Thoodzata princeps Distant, whereas in modern Aphrophora the tegmen is more pointed. Venation as in Aphrophora, with the radius curved, not straight as in Thoodzata; distance between branches of radius slightly greater than distance between lower branch and upper branch of media. Base of tegmen with the elongate-inclosed area above radius (formed by the subcosta) whitish, but the area between subcosta and costa dark-brown; below the radius the basal part of the tegmen is colorless, except for a very large obtusely cuneiform (pointed basad) mark through the middle of which runs the stem of the media; a very broad colorless band across tegmen $3.7 \mathrm{~mm}$. from base, its outer margin reaching fork of media, its lower end narrowed; beyond this light band is a large brown area about $3 \mathrm{~mm}$. long, its upper portion darkest, the principal veins remaining pale as they cross it; next, and about $8 \mathrm{~mm}$. from base, is another transverse colorless band, very broad above, with an obtuse extension along lower branch of radius, below much narrowed, and ending in an extremely oblique band crossing lower branch of media, directed basad; next follows a brown band, shaped rather like the pale one, but abruptly bent apicad and very narrow on lower branch of radius; apical area pallid, apparently more or less brownish. The radius forks about $1.8 \mathrm{~mm}$. beyond level of fork of media.

Tertiary rocks, Kudia River, Siberia.

\section{Holotype.-Cat. No. 69603, U. S. N. M.}

A very beautiful fossil, not satisfactorily separable from Aphrophora, but not like the European tertiary species assigned by Heer to that genus. Both shape and pattern recall the allied genus Thoodzata Distant, from Tenasserim.

\section{MEGACERCOPIS, new genus}

Tegmina large; costa only slightly arched; apex broadly rounded; lower margin (clavus present) straight; stem of radius directed obliquely upward, but no less than $3 \mathrm{~mm}$. below costa, giving rise to a rather broad symmetrical fork, the upper branch passing some distance below costa, and at the end abruptly deflected downward to meet the radial sector, this being anterior to the similar curved vein connecting the sector with the media; media emitting four inferior branches to the margin, which appear as pale lines on a dark ground; $\mathrm{Cu}_{2}$ (in sense of Tillyard) strong and straight; only the extreme tip of first anal preserved, this about $7 \mathrm{~mm}$. anterior to end of $\mathrm{Cu}_{2}$.

Type.-Megacercopis optima, new species. 
Plate 1, fig. 4

Tegmen so far as preserved $19 \mathrm{~mm}$. long, but the base (basad of separation of $\mathrm{Cu}_{1}+\mathrm{M}$ from $\left.\mathrm{Cu}_{2}\right)$ is lacking, and the total length would probably be about $23 \mathrm{~mm}$.; width $7.3 \mathrm{~mm}$.; fork of radius $14.6 \mathrm{~mm}$. from apex; tegmen pale, with dusky spots and patches; area above stem of radius suffusedly dusky; a dusky shade or line (only well defined outwardly) crossing the tegmen beyond level of fork of radius, receding basad at upper branch of radius (but not at sector), at media and at cubitus, between media and cubitus forming a semicircular mark; a small spot just below $\mathrm{Cu}_{2}$ near base; just beyond level of end of $\mathrm{Cu}_{2}$ are three large elongate patches, the first between branches of radius, the second between radial sector and media, and the third just beyond and narrowly connected with the semicircular mark already described; just beyond the third of these patches is another, through which runs a white line, bent beyond the middle; in subapical region, bounded by vein connecting radial sector with media, is a large oblong patch; margin of nearly apical third of tegmen brown, the interrupting veins appearing white.

Tertiary of Kudia River, Siberia.

\section{Holotype.-Cat. No. 69604, U.S.N.M.}

Scudder in 1895 remarked on the large size of the Cercopinae of the tertiary of British Columbia. The present insect shows some resemblance in its markings to Dawsonites veter Scudder, from the British Columbia Tertiary, but the structure differs. In venation, our genus suggests Scudder's Stenecphora, but the shape of the apical part is quite different.

The present Cercopid fauna of northern regions (about 25 species in America north of Mexico) is an impoverished remnant of the Cercopidae of tertiary time.

\section{Family CICADELLIDAE}

\section{LAVRUSHINIA, new genus}

Tegmen (clavus missing in type specimen) long and narrow, costa practically straight, apex broadly and symmetrically rounded; media leaving radius before end of basal third, the fork symmetrical and rather wide; large discoidal cell between media and radius elongated, squarely truncated at the beginning of the middle anteapical cell, but above narrowly contiguous with the cuneate base of the cell in the radial fork, and below more broadly with the large cell in the fork of the media, this last cell being truncate apically, but cuneate basally, with a very long oblique side on cell 
between media and cubitus; the usual upright cross-vein (supposedly end of subcosta) from upper subapical cell; the usual three rather short (but longer than high) apical cells, truncate basally, the middle one not extending so far basad as the others; cubitus straight; a broadly lanceolate cell beyond its end, at the anal corner, contiguous for an equal distance with the lower subapical and lower apical cells; marginal vein hardly separate from margin, except narrowly at the anal angle. I follow Tillyard's nomenclature, but the ambient vein, which he describes as specially characteristic of Membracidae, also exists in Cicadellidae, and sometimes is quite evidently separated from the margin.

Type.-Lavrushinia elegantula, new species.

I am at a loss to identify this with any modern genus. The venation varies so much within the genus in this family (as in Deltocephatus), that the tegmen alone is not very satisfactory for generic determination, but it seems probable that we have to do with an extinct genus. There is some resemblance to such genera as Tettigoniella and Helochara. Chunra of Distant differs at once by having the ambient vein widely separated from the margin, as Tillyard describes for the Membracidae.

LAVRUSHINIA ELEGANTULA, new species

Plate 1, fig. 2

Tegman $6.5 \mathrm{~mm}$. long, 2 broad (clavus missing); dilute fuliginous, with strong brown veins, costal margin dark, and stigmatic region infuscated.

Tertiary of Kudia River, Siberia. Found by Mr. A. I. Laxrushin, after whom the genus is named.

Holotype.-Cat. No. 69605, U.S.N.M.

\section{Family CIXIIDAE}

\section{MUNDOPOIDES, new genus}

Resembling the oriental genus Mundopa. Distant, but with nearly straight costa, obliquely truncate apex and almost straight outer margin, giving the tegmen a very mothlike aspect. A sharp, simple subcosta running just below the costa, ending on margin about middle of tegmen; radius running about a third of depth of tegmen below costa, a little before middle of wing emitting two long very oblique branches above; apical area, beyond the second pale band, with widely separated, not dense, longitudinal veins. Clavus missing in the type. The tegmen is black, with two broad light bands, as in the Cercopids Tomaspis and Cosmoscarta, but the structure is not that of Cercopidae. The outer margin is very narrowly pale, as in Ciocixius.

Type.-Mundopoides cisthenaria, new species. 
Plate 1, fig. 5

Tegmen about $11 \mathrm{~mm}$. long (the extreme base lacking); black, with two broad colorless bands; the first, not far from base, about 1.5 $\mathrm{mm}$. wide, suddenly and rectangularly constricted at inner lower corner; the second, about $1.7 \mathrm{~mm}$. wide, gently arcuate, placed 3 $\mathrm{mm}$. beyond the first band, and $4 \mathrm{~mm}$. from apex; apical margin very narrowly pallid. A round spot and a pale patch, with other slight markings, are not natural, but due to abrasion. The second band does not quite reach the costa at its upper outer corner, but on the inner side appears to be prolonged along costa; costa hardly arched; outer margin little curved, $5 \mathrm{~mm}$. long; lower margin straight (in absence of clavus), at least $9 \mathrm{~mm}$. long.

Tertiary of Kudia River, Siberia.

Holotype.-Cat. No. 69613, U.S.N.M.

The name of the species is derived from a superficial resemblance to the moths of the Neotropical genus Cisthene; the central band is placed nearly as in $C$. Tunaris Walker. The shape of the tegmen recalls the Ricaniine genus Privesa, but the structure is quite different. There is a genuine resemblance to the American genus Bothriocera, species of which have a somewhat similar pattern of light and dark markings.

\section{DIPTERA}

\section{Family BIBIONIDAE}

\section{Genus PLECIA Wiedemann}

The genus Plecia is very widely distributed over the world, but in any given fauna the species are few. It therefore seemed quite scandalous for Handlirsch to describe 20 species from tertiary rocks in two localities in British Columbia, there being only about three to-day in the whole of the Nearctic region. However, I have been able to distinguish four readily separable species in the Florissant Miocene, and in now presenting 6 from a single Siberian locality I believe I err, if at all, on the side of moderation. I do not yet believe that all of Handlirsch's 20 species are distinct, but it must apparently be recognized that in tertiary times Plecia was very rich in species, as Tipula is to-day, and indeed was then.

Brunetti, in his table of Indian Plecia, divides the species into two categories thus: $(a)$ Third $(3+4)$ longitudinal vein forking some distance beyond anterior cross vein (nearly at half the length of its lower branch), and always distinctly beyond the fork of fourth vein. (b) Third longitudinal vein forking shortly beyond anterior cross vein (distinctly before one-third of the length of its 
lower branch), and approximately opposite the fork of fourth vein; the upper branch lying almost parallel to the lower one, not almost erect as in the other division.

Divided thus, only one Siberian species ( $P$. amagua) falls in division $b$. The remaining five go in $a$, except for the fact that the upper branch (second vein) is not short and suberect as in $P$. fulvicollis. In the modern Indian fauna, the preponderance is the other way, division $b$ having three species, division $a$, only two. The common American P. heteroptera Say falls in division a, but has the upper branch (second vein) long and running nearly parallel with the lower, thus more resembling the majority of Siberian fossils than do the Indian members of this division. $P$. plagiata Wiedemann, from Guatemala, has the upper branch even more erect than in $P$. fulvicollis. It would appear that this erect or suberect branch is a character of the tropical species of both hemispheres, or at least, is lacking in those of temperate regions.

The Siberian fossils may be separated thus:

Wing less than $6 \mathrm{~mm}$. long

Wing over $6 \mathrm{~mm}$. long-_-

1. Cell in fork of vein $3(2+3)$ very long and narrow_-_._ amagua, new species.

Cell in fork of vein 3 shorter and broader.

kudiella, new speces.

2. Basal corner of second posterior cell at a distance from anterior cross vein less (or not more than) the length of cross vein_-_-_-- refracta, new species.

Basal corner of second posterior cell at a distance from anterior cross vein greater than length of cross vein 3.

3. Third vein before anterior cross vein over $2 \mathrm{~mm}$. long-- redempta, new species. Third vein before anterior cross vein less than $2 \mathrm{~mm}$. long--_-_------- 4 .

4. Upper branch of fourth vein nearly in line with stem_ kuznetzovi, new species. Upper branch of fourth vein strongly and abruptly elevated at base.

obsitula, new species.

In this key the living $P$. heteroptera runs straight to $P$. refracta. In the descriptions, I follow Williston's interpretation of the venation, but as shown below, this may be incorrect in respect to the second vein.

Plecia AmagUA, new species

Plate 2, fig. 15

Wing $5.5 \mathrm{~mm}$. long and about 2.3 broad, very pale reddish, with pale veins; fork of third vein extremely narrow, the upper part (second vein) very weak, the lower strong and strongly curved; fork of fourth vein at a distance from anterior cross vein considerably greater than length of latter; fork of third vein a little before vertical level of fork of fourth. Anterior cross vein to fork of fourth $480 \mu$.

Tertiary of Kudia River, Siberia.

Holotype.-Cat. No. 69606, U.S.N.M. 
Related to P. atra Brunetti, but with the fork of third vein even narrower, in its basal portion less than half width of fork of fourth. The fourth posterior cell is greatly widened on the margin; in this

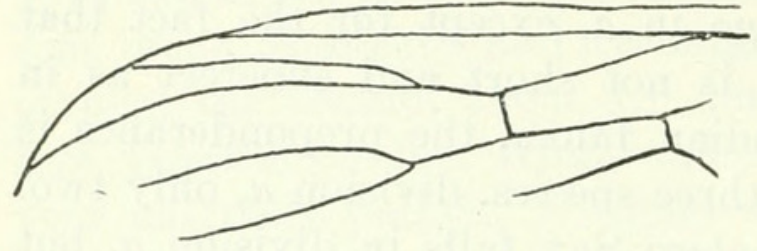

Fig. 4.-Part of venation of Plecia AMAGUA respect $P$. amagua differs from $P$. atra and resembles rather P. fulvicollis.

\section{PLECIA KUDIELLA, new species}

Plate 2, fig. 18

Wing about $5 \mathrm{~mm}$. long. Differs from $P$. amagua by being smaller, with vein 3 much less curved downward at end, and the fork (separation of 2 from 3 ) much shorter and more open, its base considerably beyond vertical level of fork of fourth. The wing is very pale, faintly reddish, with pale veins. The fork of fourth vein is wide, its base about $320 \mu$. from anterior cross vein, the latter being about $160 \mu$ long. The fourth posterior cell is little widened apically, being about as in P. atra.

Tertiary of Kudia River, Siberia.

Holotype.-Cat. No. 69607, U.S.N.M.

\section{PLECIA REFRACTA, new species}

Plate 2, fig. 21

Wing $9.6 \mathrm{~mm}$. long, 3.8 wide; moderately dusky throughout, with pale veins. Upper branch of third vein (second vein) colorless and difficult to see; fork of fourth vein to anterior cross vein about $430 \mu$, the anterior cross vein about $480 \mu$ long; anterior cross vein more than twice as far from base of third posterior cell as from fork of fourth vein; fork of third vein

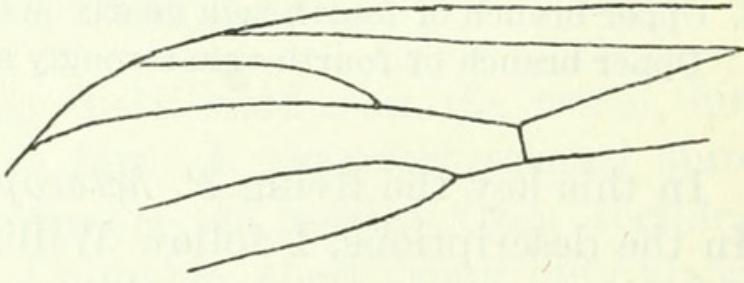

Fig. 5.-Part of venation of Plecia KUDIELLA very far beyond vertical level of fork of fourth, being about $1280 \mu$ beyond anterior cross vein; fourth posterior cell wide open at apex.

Tertiary of Kudia River, Siberia. In addition to the type, four other specimens are referred to this species.

Holotype.-Cat. No. 69608, U.S.N.M.

\section{PLECIA REDEMPTA, new species}

Plate 2 fig. 20

Wing about $8.6 \mathrm{~mm}$. long, dusky, with the upper part fuliginous, the veins dark. This resembles $P$. obsitula, but is distinct by the much longer third (really second and third united) vein before anterior cross vein, the length of this section being $2320 \mu$ (in obsi- 
tula only $1470 \mu$. ) The second posterior cell (fork of fourth vein) is also much wider, the width about middle $1200 \mu$ (in obsitula $800 \mu$.). Anterior cross vein to fork of third, about $1280 \mu$; to fork of fourth about 590 .

Tertiary of Kudia River, Siberia.

Holotype.-Cat. No. 69609, U.S.N.M.

PLECIA KUZNETZOVI, new species

Plate 2, fig. 19

Wing $7 \mathrm{~mm}$. long; differs from $P$. obsitula in being smaller, paler, with upper branch of fourth vein nearly in a line with stem (in obsitula, redempta, and refracta it is abruptly elevated at base), and second vein after separation from third nearly parallel with the latter. The third vein before anterior cross vein is $1.4 \mathrm{~mm}$.; fourth posterior cell widely open at apex; anterior cross vein only about half as long as in $P$. redempta, its distance from fork of fourth about $430 \mu$.

Tertiary of Kudia River, Siberia.

Holotype.-Cat. No. 69610, U.S.N.M.

Under a lens, it looks as if the second vein came from the first, but this is quite illusory, being due to a clouding of the wing at this point. The species is named after the discoverer of the deposit.

PLECIA OBSITUla, new species

Plate 2, fig. 17.

Wing $8.3 \mathrm{~mm}$. long, 3.4 wide, dusky, with mainly dark veins, the costal region broadly suffused with fuliginous; fork of fourth vein distant from anterior cross vein nearly 1.5 times the length of cross-vein ; cross vein slightly beyond midmost point between separation of third vein and its fork; anterior cross vein conspicuously closer to iork of fourth than to base of third posterior cell, but not nearly twice as close; fourth posterior cell widely open at apex; anterior cross vein to fork of third twice as far as to fork of fourth; upper branch of third (really second) vein abruptly elbowed at base. The type appears to be a male; two specimens with broader and paler wings are presumed to be females, the sexual difference being as in modern species.

Tertiary of Kudia River, Siberia. In addition to the type specimen, six others are referred to this species.

\section{Holotype.-Cat. No. 69611, U.S.N.M.}

In Protoplecia, from the Upper Lias of Mecklenburg, the fork of third vein is far anterior to the vertical level of fork of fourth, which would seem to indicate that the condition observed in $P$. amagua is the more primitive. From the same European deposit, 
however, Handlirsch has more recently published a genus Eoplecia, in which the third vein of Williston (radical sector) emits two branches above, one before, the other after, the anterior cross vein. Thus it may be held that the second vein is actually absent in the modern insect, and not represented by the upper branch of the third. This view is further supported by the condition in the Anisopodidae, in which the second vein arises before the cross vein, and the third is without a fork. In such Diptera as the Leptidae, the second vein arises as in Anisopodidae, but the third forks in a manner analogous to that of Plecia. Brunetti, however, argues that possibly it is the third vein which is absent in Bibionidae, and says:

If we compare a wing of Culex with that of Plecia, and simply eliminate the third vein from the former and lengthen the anterior cross vein, we get an exact counterpart in the wing of the latter.

\section{EXPLANATION OF PLATES.}

Plate 1.

FIg. 1. Megachile amaguensis, new species, $\times 31 \frac{1}{2}$.

2. Lavrushinia elegantula, new species, $\times 6$.

3. Philagra (?) kudiana, new species, $\times 3$.

4. Megacercopis optima, new species, $\times 2 \frac{1}{2}$.

5. Mundopoides cisthenaria, new species, $\times 3$.

6. Aphrophora protocalla, new species, $\times 2 \frac{1}{2}$.

7. Anthonomus amaguensis, new species, $\times 6$.

8. Throscus ( 9 ) peritulus, new species, $\times 6$.

9. Limnephilus recultus, new species, $\times 3$.

10. Patrobus (?) kudiensis, new species, $\times 6$.

11. Cleonus shareipoffi, new species, $\times 6$.

Plate 2.

Fig. 12. Indusia comminuta, new species, $\times 6$.

13. Indusia sequoiae, new species, $\times 3$.

14. Amagupsyche perlata, new species, $\times 2$.

15. Plecia amagua, new species, $\times 6$.

16. Phryganea lavruschini, new species, $\times 2$.

17. Plecia obsitula, new species, $\times 6$.

18. Plecia kudiella, new species, $\times 6$.

19. Plecia kuznetzovi, new species, $\times 6$.

20. Plecia redempta, new species, $\times 6$.

21. Plecia refracta, new species, $\times 3$. 


\section{$2 \mathrm{BHL}$ Biodiversity Heritage Library}

Cockerell, Theodore D. A. 1925. "Tertiary insects from Kudia River Maritime Province, Siberia." Proceedings of the United States National Museum 68, 1-16.

View This Item Online: https://www.biodiversitylibrary.org/item/32569

Permalink: https://www.biodiversitylibrary.org/partpdf/5751

\section{Holding Institution}

Smithsonian Libraries

\section{Sponsored by}

Smithsonian

\section{Copyright \& Reuse}

Copyright Status: NOT_IN_COPYRIGHT

Rights: https://www.biodiversitylibrary.org/permissions/

This document was created from content at the Biodiversity Heritage Library, the world's largest open access digital library for biodiversity literature and archives. Visit BHL at https://www.biodiversitylibrary.org. 